\title{
Evaluation of the prophylactic action of veterinary dental gel containing Aloe vera and green tea on calculus formation in dogs submitted to periodontal treatment
}

\author{
Avaliação da ação profilática de gel odontológico veterinário \\ a base de Aloe vera e chá verde na formação de cálculos \\ dentários em cães submetidos a tratamento periodontal
}

\begin{abstract}
Nina Gabriela Silva Gualberto ${ }^{1 *}$ (D); Lorena Priscila Oliveira Andrade ${ }^{1}\left(\mathbb{D}\right.$; Camila Fernanda Oliveira Andrade ${ }^{2}$; Paulo Eduardo Ambrósio ${ }^{3}$ (D); Amauri Arias Wenceslau4 (1); Elisângela Barboza da Silva ${ }^{4}$ (D); Mário Sérgio Lima de Lavor ${ }^{4}$ (i); Renata Santiago Alberto Carlos ${ }^{4}$ (i)
\end{abstract}

\begin{abstract}
The aim of this study was to evaluate the effect of veterinary dental gel containing Aloe vera and green tea, with and without a water additive in preventing calculus formation in dogs after all animals were initially submitted to periodontal treatment. The preventive treatment was performed on $72 \mathrm{dogs}$, which 24 received treatment with the veterinary dental gel (G1), 24 received treatment with the gel associated with a water additive (G2), and 24 dogs did not receive any treatment (G3). The animals also were subdivided into three groups according to their diet. The gel was applied directly to the dogs' teeth and $500 \mathrm{ml}$ of the additive was added to the water, three times a week. The animals' teeth were photographed every 30 days to observe the time of new deposition of dental calculus. The images were analyzed by MATLAB. The dogs in G1 showed average of new accumulation of dental calculus of 254.8 days, those in G2 also showed an average return of 258.6 days, and G3 showed an average return of 156.7 days. There was a statistical difference between G1 - G3 ( $\mathrm{p}$-value = 0,000007885) and G2 - G3 (p-value = 0,00004568). There was no statistical difference between the different food groups. We concluded that the gel used in this study, associated or not with the water additive, was effective in helping to maintain the dental health of the animals for a prolonged period after the surgical procedure to prevent the calculus return.
\end{abstract}

KEYWORDS: Periodontal disease; Oral hygiene; Prophylaxis.

RESUMO: O objetivo deste estudo foi avaliar o efeito do gel odontológico veterinário contendo Aloe vera e chá verde, com e sem aditivo hídrico, na prevenção da formação de cálculos dentários em cães, após todos os animais terem sido inicialmente submetidos ao tratamento periodontal. $\mathrm{O}$ tratamento preventivo foi realizado em 72 cáes, dos quais 24 receberam tratamento com o gel odontológico veterinário (G1), 24 receberam tratamento com o gel associado ao aditivo hídrico (G2) e 24 cães não receberam nenhum tratamento (G3). Os animais também foram subdivididos em três grupos de acordo com a dieta alimentar. $\mathrm{O}$ gel foi aplicado diretamente nos dentes dos cáes e $500 \mathrm{ml}$ do aditivo foram adicionados à água, três vezes por semana. Os dentes dos animais foram fotografados a cada 30 dias para observar o momento da nova deposição do cálculo dentário. As imagens foram analisadas pelo MATLAB. Os cães do G1 apresentaram média de novo acúmulo de cálculo dentário de 254,8 dias, os do G2 também apresentaram retorno médio de 258,6 dias, e o G3 apresentou retorno médio de 156,7 dias. Houve diferença estatística entre G1 - G3 (p-valor = 0,000007885) e G2 - G3 (p-valor = 0,00004568). Não houve diferença estatística entre os diferentes grupos de alimentos. Concluímos que o gel utilizado neste estudo, associado ou não ao aditivo hídrico, foi eficaz em auxiliar na manutenção da saúde bucal dos animais por um período prolongado após o procedimento cirúrgico para evitar o retorno do cálculo.

PALAVRAS-CHAVE: Doença periodontal; Higiene oral; Profilaxia.

\footnotetext{
'Master's in Animal Science from State University of Santa Cruz, Ilhéus, Bahia

¿Veterinarian, Vetclin Clinic, Itabuna, Bahia

sPh.D. Professor from the Department of Exact and Technological Sciences of State University of Santa Cruz, Ilhéus, Bahia

${ }^{4}$ Ph.D. Professor from the Department of Agricultural and Environmental Sciences of State University of Santa Cruz, Ilhéus, Bahia.

*Corresponding author: ninagabriella@hotmail.com

Received: 21/03/2021. Accepted: 21/05/2021
} 


\section{INTRODUCTION}

Periodontal disease is the most common oral condition among dogs and cats. It is defined as a chronic, inflammatory and infectious injury affecting structures responsible for dental support such as the gums, alveolar bone, cementum and periodontal ligament (GORREL, 2010). This injury is induced by plaque accumulation on the teeth and adjacent tissues, causing gingivitis, and with the correct treatment is reversible. Periodontitis, on the other hand, is the irreversible phase of the disease (HARVEY, 1998).

Several factors, such as age, breed, genetics, diet, plaque accumulation and dental calculus, presence of deciduous teeth, skull shape and trauma, as well as the condition of the flora of the oral cavity, promote development of periodontal disease (GORREL, 2010; NIEMIEC, 2013; ROZA; BARRIVIEIRA, 2012).

Dental plaque is formed by microorganisms that adhere to the teeth, and the accumulation of plaque can cause lesions (HARVEY, 1998). Periodontal disease occurs when the bacterial population changes from immobile gram-positive aerobic cocci to mobile gram-negative anaerobic rods. This change in oral microbiota occurs due to lack of oral hygiene (ÖZAVCI et al., 2019).

The most common sign of periodontitis is halitosis, caused by bacterial fermentation leading the animals to develop very intense bad breath (GORREL, 2010). Other clinical signs presented by dogs with periodontal disease, are excessive salivation (ptyalism), tooth loosening, severe gingivitis, gingival retraction, root exposure, anorexia, difficulty in chewing, mild to moderate gingival hemorrhage, periodontal pockets, loss of alveolar bone, nasal discharge and oronasal fistulas (BAIA et al., 2017; ROZA; BARRIVIEIRA, 2012).

In addition, severe periodontal disease is also associated with several serious systemic diseases that occur due to bacteremia (PAVLICA et al., 2008). According to Pereira dos Santos et al., (2019) the systemic diseases that have been observed include kidney, liver and heart disease, brain disorders and atherosclerosis.

Since dog saliva $\mathrm{pH}$ is alkaline, it facilitates plaque mineralization, thus promoting the accumulation of calculus (PIBOT, 2007). When the plaque is not removed periodically, deposition of calcium and other minerals from saliva occurs on the plaque, and calculus accumulates again in 3 to 24 months (BAIA et al., 2017; CAMARGO; GIOSO; CARVALHO, 2010).

The treatment of periodontal disease aims to remove plaque and calculus by scraping teeth using manual or mechanical dental instruments. However, the control of periodontal disease only by removing the sub and supragingival plaque and calculus is generally not sufficient (GIOSO, 2007; NIEMIEC, 2013). Prevention is extremely important to lengthen the period of recurrence of periodontal disease and minimize the local and systemic implications triggered by this condition, as well as to reduce the need for anesthetic-surgical procedures (GIOSO, 2007).

Several products aim to prevent the deposition of calculus in dogs and cats by delaying its formation. Among these are chewable toys and specific dry feeds (PAIVA et al., 2007). In human dentistry, natural compounds are often used for prevention or treatment of periodontal disease, and research continues to support development of new commercial products with greater pharmacological activity, less toxicity and lower cost (CASTILHO; MURATA; PARDI, 2007; FRANCISCO, 2010).

Considering the importance of maintaining good oral health of dogs, this study aimed to evaluate the action of a veterinary dental gel containing Aloe vera and green tea, with or without a water additive, in the prophylaxis of periodontal disease after periodontal treatment, and correlating the effect with the type of food received by each treatment group. This gel has already been used to treat periodontal disease and has not caused problems regarding hematology or biochemical changes due to its prolonged use (ANDRADE et al., 2019).

\section{MATERIAL AND METHODS}

\section{Ethical considerations and study site}

This study was carried out at the Veterinary Hospital of State University of Santa Cruz (UESC) located in the city of Ilhéus, state of Bahia, Brazil and was approved by the hospital's Ethics Committee on Animal Use (CEUA) under number $022 / 2014$.

\section{Animals}

Ninety-four dogs with different stages of periodontal disease were evaluated. After this evaluation, 72 healthy and docile dogs weighing up to $15 \mathrm{~kg}$, of both sexes, without breed consideration, from one year to 10 years of age, were selected.

As pre-anesthetic tests, complete blood count, serum urea, creatinine and ALT were measured, and for dogs over seven years of age, an electrocardiogram was also performed. For periodontal treatment, the animals were anesthetized using the following anesthetic protocol: $0.2 \%$ acepromazine plus $10 \mathrm{mg} / \mathrm{ml}$ of morphine with respective doses of $0.1 \mathrm{mg} / \mathrm{kg}$ and 0.1 to $0.5 \mathrm{mg} / \mathrm{kg}$ intramuscularly as pre-anesthetic medication, and intravenous propofol $1 \%$ at a dose of $6.0 \mathrm{mg} / \mathrm{kg}$ for induction. After intubation, the animals were kept in a semi-closed valve circuit with an oxygen flow of $50 \mathrm{ml} / \mathrm{kg} / \mathrm{min}$ with $1.0 \mathrm{~V} \%$ Isofluorane ${ }^{\circledR}$ and $1: 1$ nitrous oxide with $100 \%$ oxygen.

The calculus was removed using manual extractors and a veterinary dental ultrasound device (Scaler Pet Kondortech ${ }^{\circledR}$ ). 
Supra and subgingival calculus were removed and teeth with furcation exposure and mobility were extracted. The procedure was completed with polishing with a rubber cup attached to a low-speed motor and a prophylactic fluorine paste $\left(\right.$ Allplan $\left.^{\circledR}\right)$.

In the postoperative period, spiramycin at a dose of $75,000 \mathrm{IU} / \mathrm{kg}$ plus metronidazole at a dose of $12.5 \mathrm{mg} / \mathrm{kg}$ every 24 hours was introduced 2 days prior the procedure and was maintained for 8 days after the the surgery. Meloxicam at a dose of $0.1 \mathrm{mg} / \mathrm{kg}$ once daily for 5 days was prescribed after the procedure. Twenty-four hours after the surgical procedure, preventive treatment with prophylactic gel began.

\section{Veterinary dental gel and water additive}

Tropiclean Fresh Breath Clean Teeth $\mathrm{Gel}^{\oplus}$ was used as maintenance treatment. This dental gel is composed of plant extracts with known therapeutic functions, such as mint $(1.0 \%)$, Aloe vera $(1.0 \%)$, green tea extract $(1.0 \%)$ and glycerin (10.0\%).

In addition to the gel, a water additive was used (Oral Care Water Additive $\left.{ }^{\circledast}\right)$, composed of Aloe vera leaf juice (1.0\%), citric acid (1.0\%), cetylpyridinium chloride $(1.0 \%)$, sodium benzoate $(1.0 \%)$, green tea extract $(1.0 \%)$ and excipients.

The tested products were applied following the respective manufacturer's recommendations (TROPICLEAN, 2010): the gel was applied directly to the teeth, using gloves, and $15 \mathrm{~mL}$ of water additive was diluted in $500 \mathrm{~mL}$ of water, both three times a week, respecting the division of the groups.

\section{Experimental groups}

After the periodontal disease treatment, the dogs were divided into three experimental groups of 24 animals each. Group 1 received application of the gel; Group 2 was treated with gel and additive added to the water; and Group 3 (control group) did not receive any kind of prophylaxis.

To assess whether the type of food interferes with the formation of calculus, the animals within each treatment group were further subdivided according to the food provided by their owners: wet diet (homemade food such as table scraps); mixed diet (homemade food and dry commercial dog food); and dry diet (dry commercial dog food), resulting in eight dogs in each food group (Figure 1).

The maxillary dental elements on the right side (canine 104 and premolars 105 to 107) and dental elements on the left side (canine 204 and premolars 205 to 207) of all animals were photographed every 30 days to check how long it would take for the formation of the new calculation. However, if any new plaques were noticed during the weekly clinical evaluations by the investigator, the photo was taken immediately.

\section{Computer image analysis}

The images obtained every 30 days were evaluated by a computer program (MATLAB) using a digital and computerized processing technique to quantify the results obtained. The identification and comparison of the healthy and affected

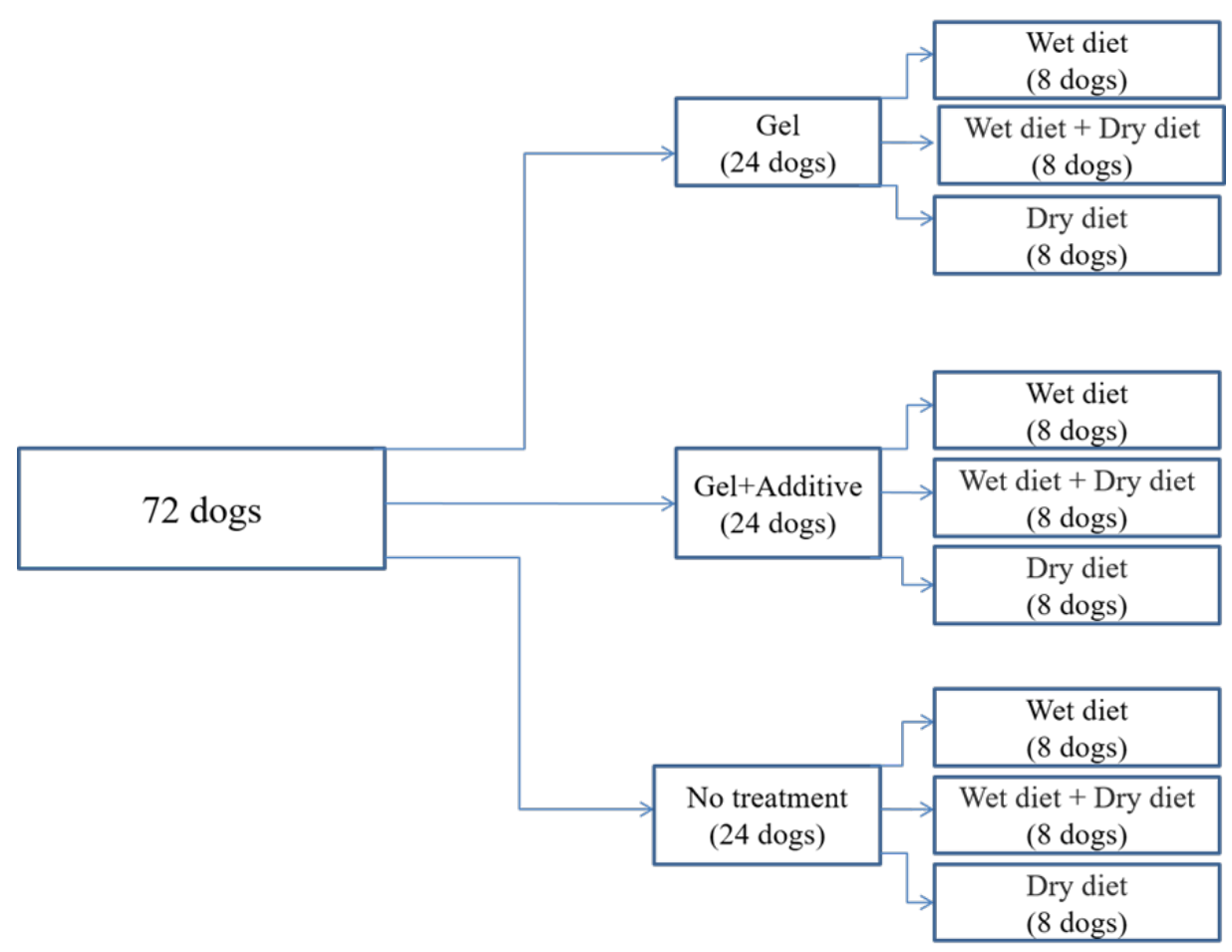

Figure 1. Organization chart detailing the division of the experimental groups according to the type of treatment provided and the diet group of the animals in the study. 
area of the animals' teeth were carried out. The adapted contour technique was applied to define the area of interest and improve image quality. This analysis was used as a tool to assist in confirming color change of teeth (Figure 2), indicating the beginning of the formation of calculus.

As soon as the presence of calculus was detected by MATLAB, the animal was removed from the study. Animals that did not show new calculus formation were monitored until 12 months after periodontal treatment.

\section{Clinical evaluation}

All dogs participating in the study received clinical followup three times a week to check if they showed changes such as apathy, changes in the color of mucous membranes, vomiting, diarrhea, loss of appetite, reduced water consumption and changes in tooth color.

\section{Statistical analysis}

To compare the variables as kinds of food (wet diet, mixed diet and dry diet) and treatment between the three groups the Kruskal Wallis test was performed and in case of statistical significance, there were performed Wilcoxon/Mannwhitney test between each two groups. All analyzes were performed with R software Version 3.5.0, considering a significance level less then 0,05, and for Mann-whitney there was done the Bonferroni correction, in with the significance for each two groups was considered when less than 0,016 .

\section{RESULTS AND DISCUSSION}

Seventy-two dogs were selected for the experiment, aged between one and 10 years, of which 45 were females and 27 males. The team responsible for the study went to the home of each animal to conduct this work, resulting in a reliable assessment.

Comparing the experimental treatment groups, the group that received only application of the gel (G1) had an average

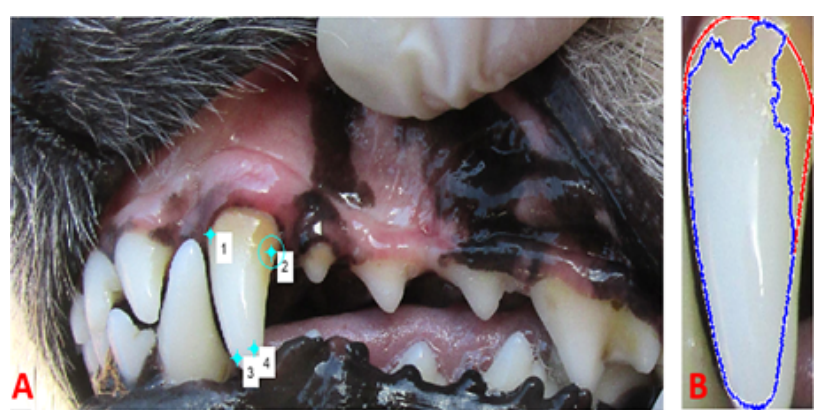

Figure 2. Image with four reference points of a study animal, after 7 months of treatment, showing how the MATLAB program reads the affected area and the healthy area of the teeth. A) Processed image of dental element 204. B) Processed image with active contour of the first and second passage, indicating healthy area (blue outline) and affected area of dental element 204. calculus return of 254.8 days, while the group that received gel associated with the water additive (G2) had an average return time of 258.6 days and the control group, which did not receive treatment (G3), presented an average return time of 156.7 days (Table 1 ).

When comparing the averages of the experimental groups, no statistically significant difference was observed between G1 (gel group) and G2 (gel group + water additive) $(\mathrm{W}=291$, $\mathrm{p}$-value $=0.9589)$ in relation to the interval of reappearance of dental calculations, however there was statistical difference between G1 (gel group) and G3 (group without treatment) (W $=71$, p-value $=0.000007885)$, as well as G2 (gel + additive) and G3 (without treatment) $(\mathrm{W}=90$, p-value = 0.00004568 ), showing that the use of the tested products promoted a longer time of maintenance of the teeth without calculation in relation to the group that did not receive any type of preventive treatment.

According to Santos; Carlos; Albuquerque (2012) and Parreira et al. (2018) physical methods such as brushing and chemical methods can be used to prevent periodontal disease, thus extending the interval between surgical dental cleaning interventions. In this study, periodontal treatment was carried out followed by the use of a gel associated or not with a water additive as a preventive method to keep the oral cavity of the animals healthy longer. In this study, although tooth brushing was not performed, it is believed that if this method were applied, the results would be even more satisfactory. We found that the products used as a preventive method in this study were effective since they prolonged the time until new calculus formation (Figure 3).

Even after total removal of the calculus and polishing, it is not possible to ensure complete absence of bacterial plaque. However, preventive measures such as plaque control will delay the formation of new calculus since plaque is the first event in the etiology of calculus formation. Thus, preventive control must be performed (BAIA et al., 2017; NIEMIEC, 2013). These observations are consistent with the results of this study.

The animals that did not receive prophylactic treatment showed average new calculus formation in approximately four months. This result corroborates the finding that new deposition of plaque occurs between 24 to 48 hours on the teeth after surgical removal of calculus, with the initiation of calcification in two weeks (PIBOT, 2007). Thus, between three to six months, there is complete accumulation of calculus on the teeth (GIOSO, 2007).

Comparing the groups of different food types, we observed that the dogs fed with a wet diet had an average return time of 211.8 days, while the dogs fed with a mixed diet showed an average return time of 213.4 days, with no statistically significant difference between the two. In contrast, dogs fed with a dry diet had a mean return time of 244.9 days, differing statistically from the other feeding groups, since they presented a longer calculus return intervals. 
Table 1. Average number of days of viewing tartar using MATLAB in different experimental groups.

\begin{tabular}{l|c|c|c|c}
\hline Treatment & Wet diet & Mixed diet & Dry diet & $\begin{array}{c}\text { Means of calculus return } \\
\text { related to type of treatment }\end{array}$ \\
\hline Gel (GI) & 266.7 & 236.5 & 261.3 & $254.8^{\mathrm{a}}$ \\
\hline Gel + Additive (G2) & 245.7 & 213.1 & 317 & $258.6^{\mathrm{a}}$ \\
\hline Untreated (G3) & 123 & 190.7 & 156.6 & $156.7^{\mathrm{b}}$ \\
\hline Means calculus return related to type of food & $211.8^{\mathrm{a}}$ & $213.5^{\mathrm{a}}$ & $245.0^{\mathrm{a}}$ & \\
\hline
\end{tabular}

Means with the same letters are equivalent ( $p>0.05)$; Means with different letters are not equivalent $(p<0.05)$.
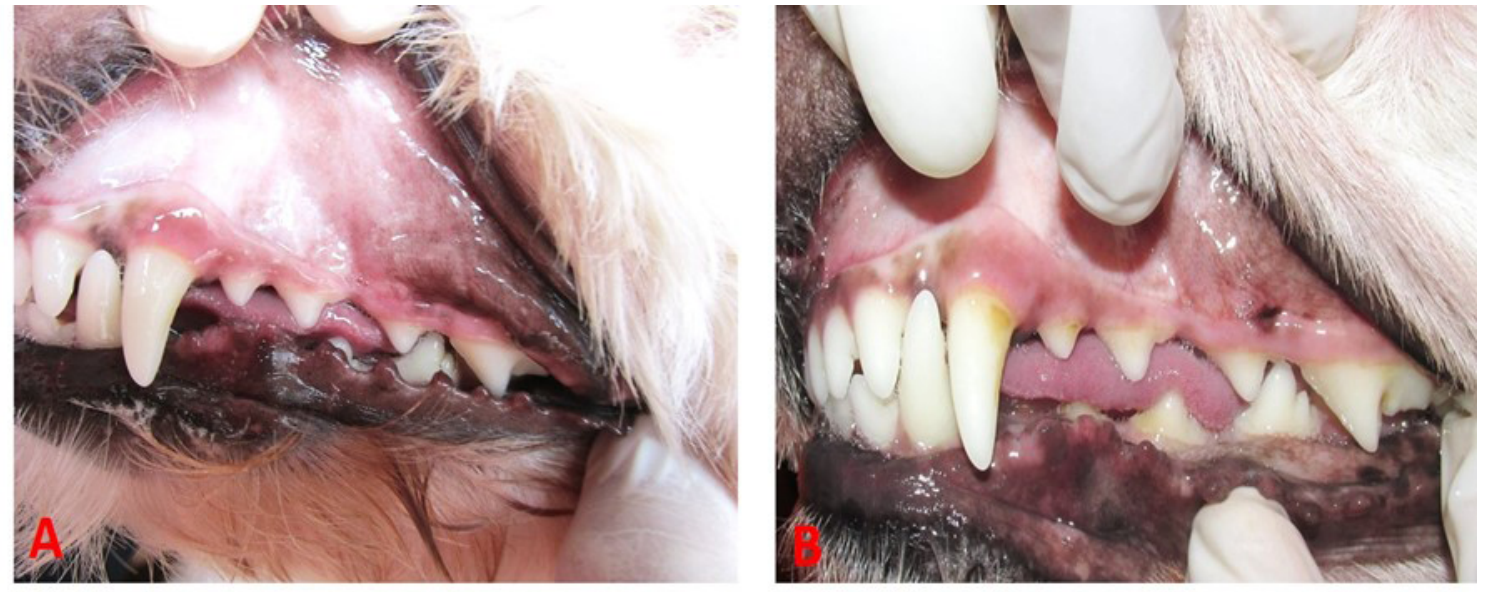

Figure 3. Dog that used maintenance treatment. A - Image taken after dental cleaning. B - Image taken 10 months after dental cleaning, showing return of calculus.

Although several studies show that the type of food influences the formation of dental calculus, in this study there was no significant difference between the different food groups. Dogs fed a wet diet and dry diet presented by the Wilcoxon test $\mathrm{W}=230(\mathrm{p}$-value $=0.2356)$. Comparing the animals fed with mixed diet and dry diet resulted in $\mathrm{W}=228(\mathrm{p}$ value $=0.2196)$. Among dogs fed a wet diet and a mixed diet, there was a result of $\mathrm{W}=278.5(\mathrm{p}$-value $=0.8527)$. These results corroborate with the studies by Sponchiado et al., (2018), that observed in their studies that the different types of food did not significantly influence the formation of dental calculus.

The products used did not cause any adverse clinical signs such as vomiting, diarrhea, changes in appetite or in teeth color. Of the 24 animals that received the water additive, 12 showed a reduction in water consumption in the first week, but after this period the water consumption normalized. This reduction in water consumption may be related to the change in the taste of the water, since normal water intake returned and no other clinical signs of disease were associated with this occurrence. As mentioned before, the prolonged use of the gel did not cause clinical changes or changes in teeth color, which is an advantage compared to prolonged use of chlorhexidine, which causes the appearance of green, brown or black spots on the teeth after continuous use for more than 15 days, and these only disappear after use is suspended (GIOSO, 2007; SANTOS; CARLOS; ALBUQUERQUE, 2012).

The computer analysis of the calculus, had reduced the subjectivity of the evaluator, making the results more reliable in relation to the visual evaluation, as it was seen in previous studies (ABDALLA et al., 2009).

\section{CONCLUSIONS}

The study shows that the gel associated or not with the water additive promoted the delayed development of new calculus in dogs that received preventive treatment, possibly related to the reduction in the oral bacterial population due to the effects of the substances Aloe vera and green tea extract, and that dry commercial food also lengthened the calculus return time.

\section{ACKNOWLEDGMENTS}

To UESC for the financial assistance and physical space. This study was financed in part by the Coordenação de Aperfeiçoamento de Pessoal de Nível Superior - Brasil (CAPES) - Finance Code 001 related to scholarships. Research grants were also provided by FAPESB and UESC.

\section{FINANCING}

Besides the governmental research agencies identified above, this study was funded by the companies Bioctal and Tropiclean, which provided the products used in the study. 


\section{REFERENCES}

ABDALLA, S.L. etal. Quantificação computadorizada dos índices de placa e cálculo dentais da imagem digital da superfície vestibular dos dentes de cães. Pesquisa Veterinária Brasileira v. 29.n. 8. P. 666-672. 2009.

ANDRADE, L.P.O. et al. Hematological and Biochemical Evaluation of Dogs Undergoing Treatment with Veterinary Dental Gel for the Reduction of Plaque and Dental Calculus. Acta Scientiae Veterinariae. v. 47. n. 1674. p. 1-5. 2019.

BAIA, J. D. et al. Periodontal disease: Literature review. Scientific Electronic Archives. v. 10. n. 5 p. 150 - 162, 2017.

CAMARGO, S. L. S.; GIOSO, M.A.; CARVALHO, V. G. G. Dor de dente: os animais, nossos pacientes, sentem ou não? Medvep - Revista Científica de Medicina Veterinária - Pequenos Animais e Animais de Estimação, Curitiba, v. 8, n. 24, p. 37-43, 2010.

CASTILHO, A. R. MURATA, R. M. PARDI, V. Produtos Naturais em Odontologia. Revista Saúde, n. I n. 1, p. 11-19, 2007.

FRANCISCO, K.S.F. Fitoterapy: An option in odontological treatment. Revista Saúde. v.4, n. 1. p. 18-24. 2010.

GIOSO, M. A. Odontologia veterinária para o clínico de pequenos animais. 2. ed. São Paulo: Manole, 2007. 142 p.

GORREL, C. Odontologia em pequenos animais. 1. ed. Rio de Janeiro: Elsevier, 2010. 256p.

HARVEY, C. E. Periodontal disease in dogs - Etiopathogenesis, prevalence and significance. Veterinary Clinics of North America: Small Animal Practice, v. 28, n. 5, p. 111l-1126, 1998.

NIEMIEC, B. A. Veterinary periodontology. 1 ed. New Jersey: John Wiley \& Sons, Inc. 2013. 372 p.

ÖZAVCIA, V. et al. Molecular detection offeline and canine periodontal pathogens. Veterinary and Animal Science, v. 8 . p. 1-6. 2019.
PAIVA, A. C. et al. Eficácia dos coadjuvantes de higiene bucal utilizados na alimentação de cães. Arquivo Brasileiro de Medicina Veterinária e Zootecnia, v. 59, n. 5, p. 1177-1183, 2007.

PARREIRA, B. F. S. G. et al. Periodontite e os fatores predisponentes em cães idosos. Revista Investigação, v. 17, ก. 5, p. 12-17, 2018.

PAVLICA, Z. et al. Periodontal disease burden and pathologic changes in organs of dogs. Journal of Veterinary Dentistry. $v$. 25, п. 2, p. 97-105. 2008.

PEREIRA DOS SANTOS, J.D. et al. Relation between periodontal disease and systemic diseases in dogs. Research in Veterinary Science. v.125, p. 136-140, 2019.

PIBOT, P.; BIOURGE, V.; ELLIOT, D.A. Encylopedia of canine clinical nutrition. 2 ed. Paris: Royal Canin. 2007. 357 p.

ROZA, M.R.; BARRIVIEIRA, M. Radiografia Odontológica. In: ROZA, $M$. R. Princípios da odontologia veterinária. led. Brasília: Ed. do Autor. 2012.v. 1 p. 68 - 75.

SANTOS, N.S. CARLOS, R.S.A. ALBUQUERQUE, G.R. Doença periodontal em cães e gatos - revisão de literatura. Medvep Revista Científica de Medicina Veterinária - Pequenos Animais e Animais de Estimação. v. 10, n. 32, p. 1-12. 2012.

SPONCHIADO, F. et al. Alterações da cavidade oral de cães e relação com o tipo de alimentação e higienização oral. Medvep - Revista Científica de Medicina Veterinária - Pequenos Animais e Animais de Estimação. v. 12. ก. 48, p. 12-17. 2018.

Tropiclean, 2010. Wentzville, MO, USA. Disponível em: https:/ tropiclean.com/product/fresh-breath-by-tropiclean-oral-caregel-for-dogs/. Acesso em: 03 june, 2020. 